\title{
Study on the National Security Education of College Student in Ethic Areas Incorporated into the National Education System*
}

\author{
Qing Cai \\ School of Arts and Cultural Communication \\ Guangxi University of Science and Technology \\ Liuzhou, China 545006
}

\author{
Qianwei Jin \\ School of Arts and Cultural Communication \\ Guangxi University of Science and Technology \\ Liuzhou, China 545006
}

\begin{abstract}
The development of college students' national security education in colleges and universities in ethnic areas is conducive to the training of all-round development of outstanding talents. And it also can vigorously safeguard the country's security, unity and national harmony. Through field research and visits, college teachers and students generally agree that national security education is very important. And they are confident and optimistic for future development. The national security education must demonstrate the characteristics of ethnic regions, respect the laws of education and teaching, and improve the quality of educating people. The construction of national security education system, the implementation of training programs for the improvement of personnel, the preparation of teaching syllabuses, and the emphasis on teaching methods, etc., should focus on scientific research. And the combination of study and research continues to promote the quality of national security education.
\end{abstract}

Keywords-ethnic areas; college students; national security education; national education system

\section{INTRODUCTION}

According to the report of the party's Nineteenth Congress, the Chinese dream will eventually become a reality with the work of generations of young people. The party and the country have placed ardent expectations on the aspirational, talented, practical and responsible young people. Faced with the current complex and volatile international situation, especially colleges and universities in ethnic areas, there are groups of outstanding young students of all nationalities in the country. Strengthening national security education is conducive to safeguarding national interests such as the unity of the country, the unity of the nation, and the stability of border areas. This topic aims to strengthen national unity. Through questionnaire surveys and field surveys, colleges and universities in Guilin, Liuzhou, and Nanning in Guangxi inspected national security education for college students. From June 2016 to March 2017, a total of 600 questionnaires were issued. It has received valid 592

*Fund Project: In 2016, Guangxi education system maintained the safety and stability research project of the school. "Study on the National Security Education of college student in ethic areas incorporated into the National Education System" (No. 20161A016) copies, and the effective questionnaire was as high as $97 \%$. In September 2017, they made the investigation on the issues involved in collecting data in Guilin, Liuzhou, and Nanning. A systematic study was carried out on national security education for university students in ethnic areas and included in the national education system. It hopes to explore feasible paths for comprehensively improving education and teaching.

\section{RESEARCH SUMMARY}

The development of national security education in colleges and universities in ethnic areas complies with the requirements of the times and social development. It is not only conducive to the cultivation of excellent talents for comprehensive development, but also can effectively safeguard the country's security and unity. Also, it is conducive to creating an atmosphere of public opinion in which nationalities are united and harmonious. National security includes its own Sovereignty and territorial security. It is also related to the practical problems of sustained and rapid development in the fields of economy, science and technology. And it should vigorously carry out national security education for university students in ethnic areas. Then, it would be conducive to shaping the good, healthy and rapid sustainable development of China in new era.

\section{A. It Is Important to Recognize National Security Education}

Some countries would safeguard homes. This understanding has risen to a certain height, which is a relatively comprehensive understanding of national security. This is an important piece of information that the research group has obtained. Through surveys, colleges and universities in ethnic areas generally agree that national security education is very important. According to the statistics, over $95 \%$ of teachers and students believe that it is the right time to carry out national security education. It is also necessary to construct a scientific and comprehensive education system and take effective education and teaching measures. It would cultivate talents with international vision, first-rate talents, and good physical and mental health for the Chinese dream of the Chinese nation's great rejuvenation in the middle of the 21 st century. And the talents could be able to maintain a firm belief in a complex and ever-changing 
international environment. And they believe that the country's future, national progress and self-development are getting better and better. Also, they would consciously put into action and safeguard national unity, social development, and national progress. It can be said that the national security education for university students in ethnic areas is of great significance. Therefore, we should actively incorporate this into the national education system based on our own reality. According to the survey data collected by the research team, colleges and universities in the ethnic areas have already actively implemented national security education. They have generally adopted military education, political situation policies, and thematic activities of the caucus. They have conscientiously safeguarded national sovereignty and territorial integrity, national unity, and social development. Standing at the point of national security education, they believe that colleges and universities in ethnic areas must use their own advantages to do a good job in ensuring talents service and social services for ethnic minority areas. "It is to train them to love the motherland, love the nation, love their homeland, serve the frontier construction, and maintain the sense of responsibility and mission of national security. "[1] It should vigorously carry out national security education. And they will train more outstanding talents. The colleges and universities should organize the graduates to more places where they need to realize their dreams. These graduates would take root in ethnic areas to make contribution to the country's prosperity and development. They would take actual actions to compose new poems for the development of national security.

\section{B. The Recognition of Teachers and Students in Colleges and Universities Is in Place}

The research team conducted more than one year of research from June 2016 to September 2017. According to its own in-depth study of colleges and universities in Guangxi, as well as questionnaire surveys commissioned by colleagues and classmates, the author would use business trips, and seize the opportunity to go to Guangdong, Yunnan, Hunan, etc. They had extensive exchanges and communication on the implementation of national security education in colleges and universities. And they believed that the data collected by the survey were objective and fair. The ethnic relationship in the southwestern border areas of China is united and harmonious, and social stability is good. This is a positive and beneficial aspect. The southwestern frontier has been deeply integrated into the Chinese nation with more than 60 years of development since the founding of the People's Republic of China. The people of all ethnic groups are proud of being a member of the Chinese nation. They are particularly willing to work under the leadership of the Party and the government. And they would make the contribution to two-hundred-year construction. It can be said that this is a good and encouraging message. The understanding of teachers and students in colleges and universities does not stop at this level. Instead, it shows a certain level of urgency. They believe that it is necessary to take preventive measures. When we see harmony and stability, we must think that it may have crisis. As a result, it is necessary to strengthen national security education. In particular, in the new era, we must strengthen education for the economy in the fields of science, technology, and information. And we must prevent the speculators at home and abroad from drilling into the loopholes. In order to form external competition, we must have certain advantages. To develop national security education should cater to the development of the times among young people, including university students. The patriotic love for the family is to consciously provide necessary support for creating high-speed development in the fields of economy, science and technology. Thus, colleges and universities in ethnic areas would carry out the national education system. The national security education must embody the timeliness, adapt to changes at home and abroad, and promote the education and teaching in higher level.

\section{To Be Confident and Optimistic about the Development of the Country}

According to the analysis of collected data, the vast majority of college teachers and students are full of selfconfidence and optimism about the future development of the country. They have relatively comprehensive information on reading and studying. With the advantages in human, material, and geography, the hard-working, wise and innovative China would be able to stand at the center of the world stage. National security education is not only to strengthen people's protection of the country's overall interests, but also to create an environment of confidence and optimism for the future development of the country. It is conducive to the early realization of China's "two-hundredyear" construction. In ethnic areas, the inclusion of national security education in the national education system is based on the original education. According to China's great ideal of actively constructing the community of human destiny in the new era, it is necessary to cultivate more talented people who are willing to play the role. They should have the sense of mission and responsibility. Also, they should have the ability to use practical actions to promote the sustainable development of society. Because of different university majors, different learning contents, and different jobs to be performed in the future, the quality of the national security education conducted by the training personnel is the same. It is to cultivate the students' firm belief in the need for allround development of the country. For this goal to be achieved, we must combine the policies and systems, facilities and equipment, and effective means of education and teaching to inherit the traditional Chinese excellent culture. We must grasp the rare opportunities created by the reform and opening up and use the accumulated solidity. It is based on the development trend of China becoming closer to the center of the world stage. Its further fosters an optimistic outlook on development and consciously links personal destiny with national development of the country. The goal is to give full play to the positive energy of young talents. And then, it would build a brighter and happier future.

\section{RESEARCH EMPHASIS}

For the ethnic minority areas, they must pay attention to their own characteristics in carrying out national security education. The task group believes that ethnic relations in the 
southwest region are harmonious. And the overwhelming majority of the people conscientiously safeguard the stability and unity of the country. Therefore, the key is to use education and teaching methods to solve the contradictions between insufficient development and imbalance. The students will use their own advantages to provide action support for the country's better development. That is to say, they can devote themselves to the construction of the country. And they would pay full attention to building a strong, prosperous, democratic, civilized, harmonious and beautiful nation of China at an early date.

\section{A. To Highlight the Characteristics of Ethnic Regions}

First is to focus on pertinence. China's 56 nationalities and regions are all different. The task group believes that the southwest region should go further on the basis of harmonious and united ethnic relations. The focus is to keep pace with the development of the times and attach importance to network security and information security related to national security and security issues in economic development. According to the results of Guangxi's research, it borders on Southeast Asian countries. The drug traffickers who are eager to make windfall often use the information on the Internet to achieve the purpose of drug trafficking. Therefore, the national security education carried out needs to explicitly address such phenomena. Second, it is operational. National security education must not only improve students' national security awareness, but also consciously safeguard the united and harmonious national relations. It is more important to guide students in mastering problem-solving skills. In other words, it should guide students to learn how to solve national security problems. And the students should learn relevant policies and laws, and master skills. The students should be able to solve problems that may arise in the country's security. The third is to inherit the fine traditions of the nation and to make the development and innovation in the new era. In the history of various ethnic groups in Guangxi, there were glorious achievements at the national crisis that sacrificed everything to safeguard national interests. Therefore, it can be effectively translated into the content of education and teaching, guiding students to inherit this glorious tradition. And it would carry forward the social development in the new era. Also, we have set an example to take the lead in defending our national interests.

\section{B. To Respect Education Laws and Focus on Quality} Assurance

The inclusion of national security education in the national education system in ethnic areas is of great significance. To better promote this work, we must respect the laws of education and improve the quality of education. The American humanism education theory believes that only respecting the subject of learning and creating a positive and progressive learning environment will allow learners to learn in a state of physical and mental pleasure. According to the survey of student feedback information, we must actively create a learning environment that is conducive to national security education. The first is to combine the traditional culture of patriotism and defending aggression. It should fully exploit the glorious deeds left by the ancestors of history to dare to resist the invasion of powerful enemies, and to use the representative cases against western powers in modern history. This hot spot in Guangxi has written a large number of books to safeguard the dignity of the Chinese nation. In the historical poetry, Mrs. Va played a spirit of resisting and wining in the Lingnan region. She successfully defeated the invasion and left people with praises. Feng Zicai led the Zhuang siblings to defeat the French invaders. These glorious historic cases can be used in many ways. The second is to use traditional principles of teaching students in accordance with their aptitudes. Combining learning and thinking, it should adopt appropriate methods according to the object and content of education and teaching. Each student can be effectively promoted in the learning process. In particular, it is necessary to guide students to clearly understand the changing international situation and reach out to a large number of worldwide useful information. Also, it guides students to use the online platform to participate in learning. And it would stimulate students' enthusiasm and behavior. Teachers and students work together to promote the quality of education.

\section{The Key Is to Cultivate Talents}

National security education is a systematic project. The key to testing quality lies in whether or not the educated person meets the requirements. Therefore, we must focus on the following aspects. First is the quality. They must love the motherland and people. And they must maintain national solidarity and progress. These are hard targets. There is no blurring boundary. "As the builder and successor of the socialist cause, college students are the nation's future and hope. And they are also the object of hostile forces. Improving college students' national security awareness is related to the long-term stability of the country. [2] Particularly, when the developed countries compete for young people who have weaker will with material treatment, they still need to carry forward the spirit of "two bullets and one star". It should guide students to be proud of their lives and their national life. According to research groups, the degree of recognition is very high. College teachers and students generally believe that ethnic areas need more patriotic devotees. The second is that cultural studies should be rigid. And the transformation and application of modern social scientific and technological achievements are extremely broad. To better reflect self-worth and to better serve the country, the students need to have the cultural knowledge that adapts to the development of the times and feel free to master the work skills. Third, the skills should be perfect. Graduates must have the technical skills to adapt to the Internet age for national construction. In order to learn to solve the problems encountered in the real world, students must have the technical ability to adapt to the network age. Only in this way can college students be members of outstanding talents.

\section{IMPLEMENTATION PATH}

The national security education for undergraduates in ethnic areas should be integrated into the national education system. Practical investigations and feasible implementation 
measures must be incorporated. According to survey visits and practical activities of teachers and students, research is mainly conducted in the areas of education system, teaching practice, and scientific research to confirm scientific and efficient national security education practice path.

\section{A. To Emphasize the Construction of Education System}

According to the principle of combination of system construction and practice implementation, the system construction has rules to follow. The education and teaching activities include active exploration by teachers, and experience summarization of a large number of practical activities. Combining national laws and policies of colleges and universities, the self-education management system provides an important reference for each major to further develop national security education. At the same time, it also needs to consider the relevance of practical teaching and gives teachers and students plenty of space for spontaneous organization activities. And then, it would absorb relevant laws and policies and transform them into teaching practices in colleges and universities. It would show the mysteries of learning to use. Then, the students have a sense of achievement in their practice. National security education is included in the national education system. At the school level, experts, teachers, and students are required to conduct argumentation in accordance with national laws and regulations. There are guidance opinions from professional experts, as well as a solid inspection of teaching practice activities. Through the discussion, teachers and students seriously listened to suggestions. Then, it should promote the establishment of a distinctive education and teaching system, and intensify detail management during the implementation process. The theories should be in accordance with practice. The practical ideas should promote theories. And then, it should integrate national security education in ethnic regions into the national education system. And it reflects the sustainable development of education. It focuses on the value and influence of the epochal elements in practical teaching. And implementing national security education mainly aimed at the confusion and misunderstanding of college students on the issue of national security. It should improve the effectiveness of national security education. [3] It should actively construct a national security education system that embodies the characteristics of ethnic regions.

\section{B. To Implement Teaching Behavior}

In order to carry out teaching activities closely around national security education, it is imperative that we must complete self-characteristic and innovative teaching work with the cooperation of experts and professionals. The first is to improve personnel training programs. National security education has long been reflected in many related courses. The carried out military education, legal education, and the situation and policies all contain the content of national security education. However, the emphasis is to build a more scientific and effective education system in the sense of talent training program. It would highlight the standards for cultivating outstanding talents. Especially, it would integrate related teaching curriculum resources, and provide a comprehensive curriculum system for the implementation of national security education. The second is the preparation of the syllabus and the introduction of guidance materials for national security education courses. It must be based on cultivating cultural talents that are compatible with the development of the country's national security literacy. It should provide feasible teaching solutions for solving difficult teaching points and be able to successfully complete teaching. The process provides specific design ideas and solutions. The third is the application of teaching methods. The contemporary college students live in rich material and spiritual life. The new era has new requirements for their own learning, communication methods, etc. Also, it would have higher expectations. Therefore, we need to absorb scientific and effective methods of teaching at home and abroad. We must use modern techniques to optimize teaching in the classroom. Students should be the main body. Teachers and students should actively interact with each other to do well in and out of the classroom. They should actively explore the laws of national security education comprehensively. The high quality and all-round development of excellent talent lays the foundation.

\section{To Focus on Scientific Research}

According to the education and teaching practice, it rises to a certain theoretical height. It is to carry out systematic scientific research. The first is to conduct research on the issue of national security education issued by the education department. China has completed a systematic legal system. And education departments at all levels have increased the efforts to lead university teachers and students in implementing national security education to conduct scientific research. And they actively conduct research on relevant issues, complete high-quality research reports, and publish series of papers to lay a solid foundation for further in-depth research. The second is to promote teaching through scientific research. A large number of investigations and studies can sum up work experience and even failures. These successes or failures are worthy of serious treatment. They can guide education and teaching in depth and avoid detours. It would avoid unnecessary troubles. The same teaching activities have provided the possibility of summarizing the theoretical framework of regularity. It can improve the learning effect of teachers and students, and the level of scientific research. The combination of study and research can produce more education and teaching achievements. The third is to improve students' scientific research capacity. The State invests large sums of money to carry out innovation and entrepreneurship training programs for undergraduates to cultivate scientific research abilities. Under the guidance of teachers, the State can conduct investigations and research on any topic in the field of national security education. Peers of the same age are more likely to make the communication. And it is easier to find solutions to solve existing problems. This will help the university students develop innovative awareness and practical ability. Also, it would help cultivate the reserve forces for deepening national security education research and continuously improve the education quality of the country. 


\section{CONCLUSION}

Based on the survey, colleges and universities in ethnic areas generally agree that national security education is particularly important. Developing national security education must highlight the characteristics of ethnic regions, adapt to the development of the times, respect the laws of education, pay attention to the construction of education systems, implement teaching behavior, and increase scientific research. The purpose of the effort is to cultivate excellent talents for all-round development, and to safeguard national security and unity, national harmony, and social and economic development. From the perspective of the national education system, through the joint efforts of teachers and students, we will actively promote the quality of national security education with the characteristics of ethnic regions.

\section{REFERENCES}

[1] Li Huaming. Educational implication of minority college students' ideology security[J]. Academic Forum, 2013(5). 李华明. 论少数民族 大学生意识形态安全的教育意蕴 $[\mathrm{J}]$. 学术论坛, 2013（5）.

[2] Qin Xiaohua, Li Liaoning. History review and future development of national security consciousness education for undergraduates since the reform and opening-up[J]. Party Construction and Ideological Education in University, 2014(9). 秦晓华, 李辽宁.改革开放以来大 学生国家安全意识教育的历史回顾及未来发展 [J]. 学校党建与思 想教育, 2014 (9) .

[3] Cao Xiaofei. Exploration of national security consciousness education for university students in Internet age[J]. Education Review,2012(5). 曹晓飞.网络时代大学生国家安全意识教育探索 $[\mathrm{J}]$. 教育评论, 2012 (5). 